\title{
The resistance of hazel (Corylus avellana) to hazelnut weevil (Curculio nucum L. - Coleoptera, Curculionidae). Part II. The physicochemical characteristics of the pericarp and dynamics of nut development and cultivar resistance to the pest*
}

\author{
ZDZISLAW PISKORNIK*, ALEKSANDRA MAZUR*, JERZY KORFEL*, \\ KRYSTYNA KORALKOWSKA**, BARBARA MAZIARZ*** and JACEK DĘBSKI****
}

*Laboratory of Plant Physiology, ${ }^{* *}$ Laboratory of Botany, ${ }^{* * *}$ Laboratory of Plant Protection (Faculty of Horticulture), ****Institute of Mechanization and Power Engineering in Agriculture (Faculty of Agricultural Technology and Power Engineering) - Agricultural University of Cracow, Al. 29 Listopada 54, PL 31-425 Kraków, Poland

(Received: June 23, 1988)

\begin{abstract}
Significant differences were found among the 22 studied hazel cultivars (Corylus avellana L.) in their resistance to hazelnut weevil (Curculio nucum L.) which is the main pest of this crop in Europe. The study investigated the relationships between the resistance of the cultivars to the pest and the physicochemical properties of the pericarp, i.e. the lignification dynamics, changes in thickness and hardness during nut development and the rate of nutlet development. Correlation analysis showed that there was no dependence between the physicochemical properties of the pericarp and the resistance of the hazel cultivars to the hazelnut weevil. Nut development dynamics were also found to be unrelated to resistance to the pest. Laboratory feeding experiments showed that during the initial feeding phase and at the time the insect searches for an oviposition site, it seems to prefer cultivars with the largest nutlets. However, in the period of intensive oviposition, traits other than nutlet size seem to be decisive for the beetles choice of cultivar.
\end{abstract}

\section{INTRODUCTION}

Studies conducted in 1981-1985 (Pisk ornik, 1989) showed that the hazel cultivars (Corylus avellana L.) grown in southern Poland differ significantly in their resistance to hazelnut weevil (Curculio nucum L.). Six resistance classes were distinguished, ranging from resistant (class I) to very susceptible (class VI). From among the 24 studied cultivars, 11 were classified as belonging to the first

* This study was partially financed by the Polish Academy of Sciences through program No. MR II/7.2.2.1. 
three resistance classes incompassing the most resistant cultivars. The remaining cultivars showed considerable susceptibility to the weevil.

In the next of a series of studies aimed at understanding the mechanism of the resistance of certain hazel cultivars to hazelnut weevil, the rate of pericarp lignification, its thickness at oviposition, hardness of developing nutlets, more precisely, the force needed to pierce the pericarp, the nutlet development dynamics and feeding frequencies on nutlets of various sizes during the period prior to oviposition, were examined.

\section{MATERIAL AND METHODS}

Plant material. The study was conducted on 22 hazel cultivars (Corylus avellana L.) from the plantation belonging to the Experimental Hazel Breeding Center in Kraków. The plantation was described and the resistance of the cultivars to hazelnut weevil in 1981-1985 was reported in a previous paper (Pisk ornik, 1989).

Resistance of cultivars. The percentage of nuts damaged by hazelnut weevil larvae was calculated in samples of 100 mature nuts taken from each of 4 shrubs of each cultivar. Resistance was determined according to a 6 point scale:

$$
\begin{aligned}
& \text { class I - resistant }(0-2 \% \text { damaged nuts), } \\
& \text { class II - fairly resistant }(2.1-5 \% \text { damaged nuts }), \\
& \text { class II - moderately resistant }(5.1-10 \% \text { damaged nuts }), \\
& \text { class IV - moderately susceptible }(10.1-20 \% \text { damaged nuts }) \text {, } \\
& \text { class V - susceptible }(20.1-50 \% \text { damaged nuts), } \\
& \text { class VI - very susceptible (over } 50 \% \text { damaged nuts). }
\end{aligned}
$$

Pericarp lignification. The degree of pericarp lignification was determined in longitudinal sections of nutlets and in growing nuts by staining with floroglucine and hydrochloric acid, the reaction used to localize lignin in plant tissues (Broda, 1971). The distribution of lignified tissues was marked on drawings of the longitudinal sections. The degree of pericarp lignification was expressed in a 6 point scale (from 0 to 5):

0 - lack of lignin in the pericarp tissue,

1 - start of lignification of the pericarp at the nut tip,

2 - lignified pericarp at the nut tip (about $1 / 5$ of the nut circumference),

3 - lignified pericarp of the upper half of the nut,

$4-3 / 4$ of the nut circumference lignified,

5 - entire pericarp lignified.

These determinations were made in 1981 on the nutlets of 14 hazel cultivars during the period of intensive oviposition (July 15) and in 1982 on 9 cultivars during 4 periods: July 6 and 23, August 10 and September 1 . The cultivars for these determinations were chosen so that each resistance class was represented 
by at least one cultivar. Ten nuts from each cultivar were examined on each date.

The dynamics of nut development. The size of the nuts and their embryos + cotyledons were measured during development in 9 hazel cultivars from different resistance classes. These measurements were made on longitudinal sections of nuts in 1982 on the same dates that the lignification of the pericarp was determined, using 10 nuts from each cultivar on each date.

Pericarp thickness. The thickness of the pericarp was measured using a micrometer screw or binocular equipped with a micrometer scale. The pericarp was measured in the middle of the nut on July 10,1981 using material from 16 hazel cultivars and on July 6, 1982 using 9 cultivars. These dates corresponded to, respectively, intensive oviposition and start of oviposition by the weevil females. Ten nuts from each cultivar were measured on each date.

Hardness of the pericarp. The hardness of the pericarp (shell) of growing nuts was measured using a PEL-1 penetrometer, developed by Dr. J. Dębski. This apparatus, along with the set of 9 exchangeable springs made of steel wire of various diameters is shown on Figure 1. The penetrometer is made of a sliding element (1) set in motion by a hand driving screw (2) which presses a spring (3) which, in turn, exerts increasing pressure on a head equipped with a cone-tipped bolt. The nut is placed between the head (4) and a manually adjusted regulating screw (5). Metal discs for holding the nut can be placed on its ends, but due to the variability in the size and shape of the nuts, were not

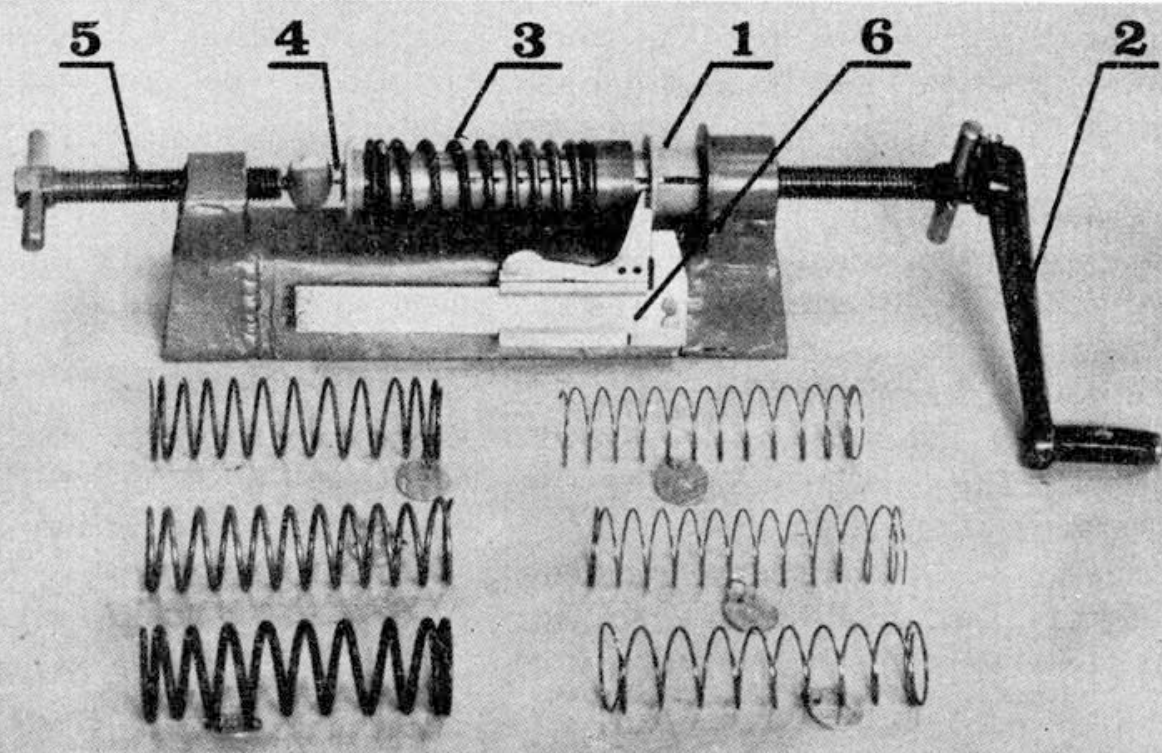

Fig. 1. Penetrometer PEL-1 with exchangeable springs for measurement of nut pericarp hardness during the development of hazelnuts (designed by Dr. Jacek Dębski)

Explanations: 1 - sliding element with a flange pushing a mobile nonius arm; 2 - handle with a driving screw; 3 - spring pressed by the sliding element; 4 - head with a calibrated bolt for breaking through the pericarp; 5 - regulating screw; 6 - nonius 
used in this study. The sliding element (1) is equipped with a flange which rests on one of the jaws of the nonius (6). A turn of the handle thus slides element (1) and moves the moveable part of the nonius. The appropriate pressure of the spring leads to the head with the bolt piercing the pericarp of the nut. The head is constructed in such a way that when the nut is pierced, the moveable part of the nonius does not spring back and so it is possible to get an exact reading on compression of the spring. We expressed it in $\mathrm{mm}$ and it is the basis for calculating the force in Newtons (N) necessary to pierce the nut according to the following formula:

$$
F=b s+a,
$$

where: $F-$ the force necessary to pierce the pricarp, in Newtons (N),

$s$ - the compression of the spring in $\mathrm{mm}$,

$a$ and $b$ - parameters of the equation determined empirically by the designer for each spring.

The pericarp hardness was measured in 20 cultivars on July 9 and August 5 , 1982. Ten nuts from each cultivar were measured. The first date corresponded with the period of oviposition by the insect, while the other with the hatching and development of the larvae in the nuts.

Feeding preference of the weevil. The experiments on the feeding preferences of the hazelnut weevil were done under laboratory conditions on June 23-25, 1983 in the initial feeding stages of the weevil on the nutlets of 19 hazel cultivars. The method of long-term feeding, described in a previous paper (Piskornik, 1989) was used. Two nutlets from each cultivar were placed in plastic trays and 5 weevils were introduced into them. The trays were then covered with glass panes and left at a temperature of $23 \pm 1^{\circ} \mathrm{C}$ for a period of 48 h. After this time the weevils were removed from the trays and the number of punctures in the nutlets from feeding by the weevils, counted. The insects used in this experiment were kept without food for $24 \mathrm{~h}$ in the same temperature as above prior to the experiment. The experiment was done in 5 repetitions ( 5 trays). The feeding preference of the weevils in respect to the various hazel cultivars was determined on the basis of the number of punctures in the nutlets. The breadth and height of the nutlets used in this experiment were also measured. The correlation coefficients between the size of the nutlets of the particular cultivars and the mean number of punctures in the pericarp were calculated. The size of the nutlets was expressed as the mean value of the product of their breadth and height. The resistance class of the hazel cultivars was taken according to the results from 1982 (Piskornik, 1989).

\section{RESULTS}

Table 1 presents most of the obtained results. The hazel cultivars used in this study, the mean percentage of nuts damaged by the hazelnut weevil and classification of cultivars on the basis of their resistance are given in columns 2 , 
3 and 1 , respectively, in this table. The data on the degree of damage to the nuts in the total yield are mean values from 5-year determinations done in 1981-1985 and have been taken from a previous paper (Piskornik, 1989).

The degree of lignification of the pericarp of hazel nutlets determined during the period of intense oviposition was found to be significantly varied (column 4, Table 1). All of the nutlets showed greater or lesser amounts of lignin in the pericarp tissue during this period. From the two most susceptible cultivars, cv. Earliest had only the tip of its nutlets partly lignified (degree 1), whereas in cv. Novoviejski, lignification encompassed $1 / 2$ and $3 / 4$ of the pericarp (degrees 3 and 4). The degree of lignification of the more resistant cultivars (classes I-III) was somewhat less diversified (degree 2 in cv. Lenka-III and degree 4 in cv. Warsaw Red). No significant correlations between the degree of nut damage by the pest and the lignification of the pericarp during oviposition was found, which is illustrated by the value of the correlation coefficient shown at the bottom of columns 3 and 4 of Table 1 . The negative sign and low value of this coefficient indicate that only a slight tendency for somewhat more frequent oviposition in nutlets having less lignified pericarps is noticeable.

The changes in the lignification of the pericarp of nutlets from 9 cultivars of various degrees of resistance, determined on 4 dates encompassing almost the entire developmental period of the nut, are presented in Table 2. The data presented therein show that there is no relationship between the lignification dynamics of the pericarp and the resistance of cultivars to the pest. The resistant cv. Lenka-II and moderately resistant cv. Carol had similar pericarp lignification dynamics to that of the rather susceptible cv. Frango-II. Even greater similarity in their lignification pattern and dynamics was shown by the resistant cultivar Hall's Giant and the very susceptible cultivars Novoviejski and Earliest. There was, however, a distinct correlation between the maturation date of the nuts and the lignification rate of the shell. The lignification of the pericarp in late cultivars (cvs. Lenka-II, Frango-II and Carol) proceeded more slowly than in the early cultivars (Earliest and Warsaw Red), although in the moderately late cultivar, Wonder from Bollwiller, lignification of the shell ended very early.

The dynamics of nut development, that is, of the pericarp and the embryo with its cotyledons, in the same 9 hazel cultivars determined on the same dates, is presented on Figure 2. The measurements made on July 6 show that the size of the nutlets is very varied, both in the group of more resistant cultivars (classes I and II) and in those more susceptible to the pest (classes IV, V and VI). The largest nutlets were found in the cultivars Wonder from Bollwiller (class I) and Novoviejski (class VI), medium-sized in Hall's Giant (class I), Warsaw Red (class III) and Earliest (class VI), whereas the remaining 4 varieties had small nutlets. Two ovules were visible inside, of which one developed into an embryo, the other deteriorated. In some of the cultivars, only 
Table 1

The relationship between the percentage of nuts damaged by hazelnut weevil and the degree of pericarp lignification, as well as between the class of hazel cultivar resistance to the pest and the pericarp thickness and hardness in developing hazelnuts

\begin{tabular}{|c|c|c|c|c|c|c|c|}
\hline \multirow{2}{*}{$\begin{array}{l}\text { Class of } \\
\text { resistance }^{1}\end{array}$} & \multirow{2}{*}{$\begin{array}{c}\text { Cultivar - English of German } \\
\text { name and Polish name } \\
\text { (in parenthesis) }\end{array}$} & \multirow{2}{*}{$\begin{array}{c}\text { Mean } \\
\text { percentage } \\
\text { of damaged } \\
\text { nuts } \pm \mathrm{SE}^{1}\end{array}$} & \multirow{2}{*}{$\begin{array}{l}\text { Lignification } \\
\text { in the } 6 \\
\text { point } \\
\text { scale }^{2}\end{array}$} & \multicolumn{2}{|c|}{ Pericarp thickness in $\mathrm{mm}$ at } & \multicolumn{2}{|c|}{$\begin{array}{l}\text { Pericarp hardness in } \mathrm{N} \\
\text { (Newtons) }\end{array}$} \\
\hline & & & & $\begin{array}{l}\text { beginning } \\
\text { of oviposition } \\
(6 \text { VII 1982) }\end{array}$ & $\begin{array}{c}\text { period } \\
\text { of intensive } \\
\text { oviposition } \\
(10 \text { VII 1981) }\end{array}$ & 9 VII 1982 & 5 VIII 1982 \\
\hline II - fairly resistant & $\begin{array}{l}\text { Lenka-IV } \\
\text { Carol (Karol) }\end{array}$ & $\begin{array}{l}3.8 \pm 0.4 \\
3.9 \pm 0.6\end{array}$ & $\stackrel{3}{2-3}$ & 0.53 & 0.75 & 2.0 & 75.1 \\
\hline $\begin{array}{l}\text { III - moderately } \\
\text { resistant }\end{array}$ & $\begin{array}{l}\text { Lenka-III } \\
\text { Gubener Zellernuss (Gubiński) } \\
\text { Warsaw - Red } \\
\text { (Warszawski Czerwony) } \\
\text { Webb's Prize Nut } \\
\text { (Webba Cenny) } \\
\text { Volski Round } \\
\text { (Kulisty Wolski) }\end{array}$ & $\begin{array}{l}9.1 \pm 1.1 \\
9.4-0.6\end{array}$ & 2 & 0.51 & $\begin{array}{l}0.99 \\
1.45\end{array}$ & $\begin{array}{l}3.5 \\
3.3\end{array}$ & $\begin{array}{l}62.9 \\
93.5\end{array}$ \\
\hline
\end{tabular}




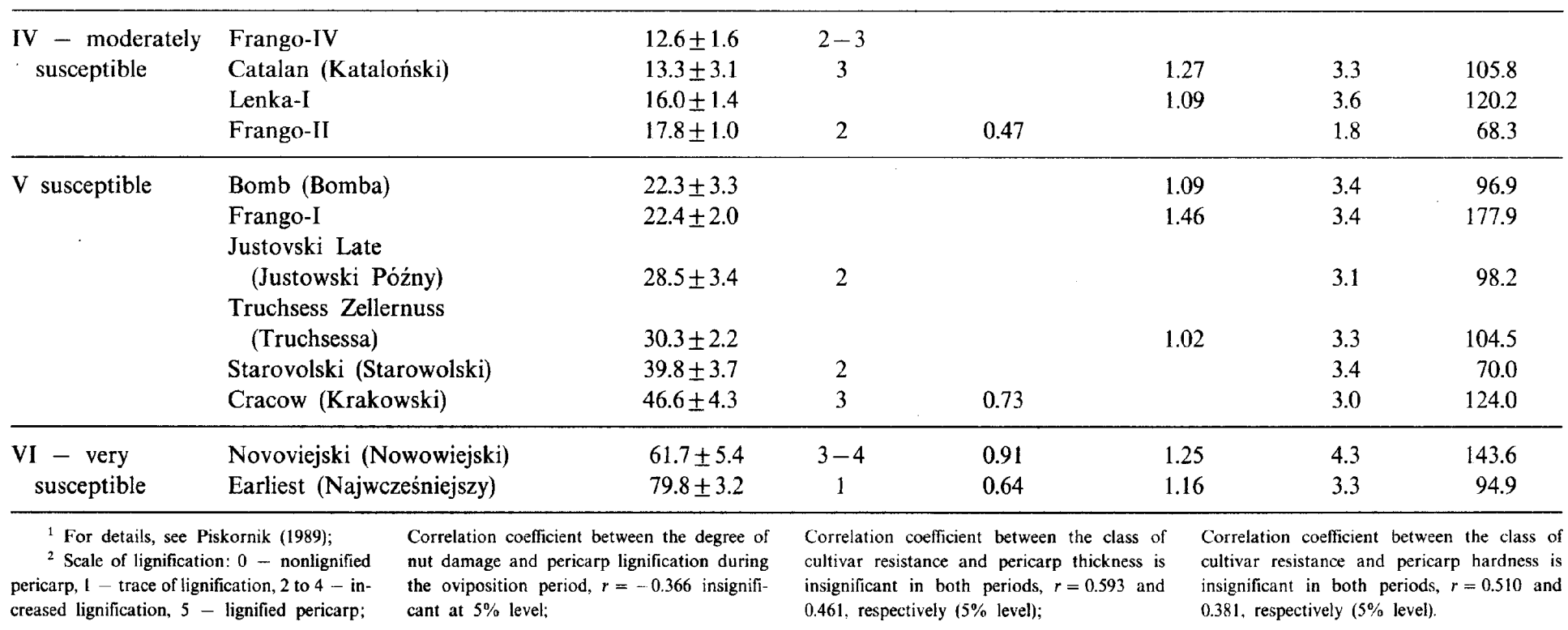




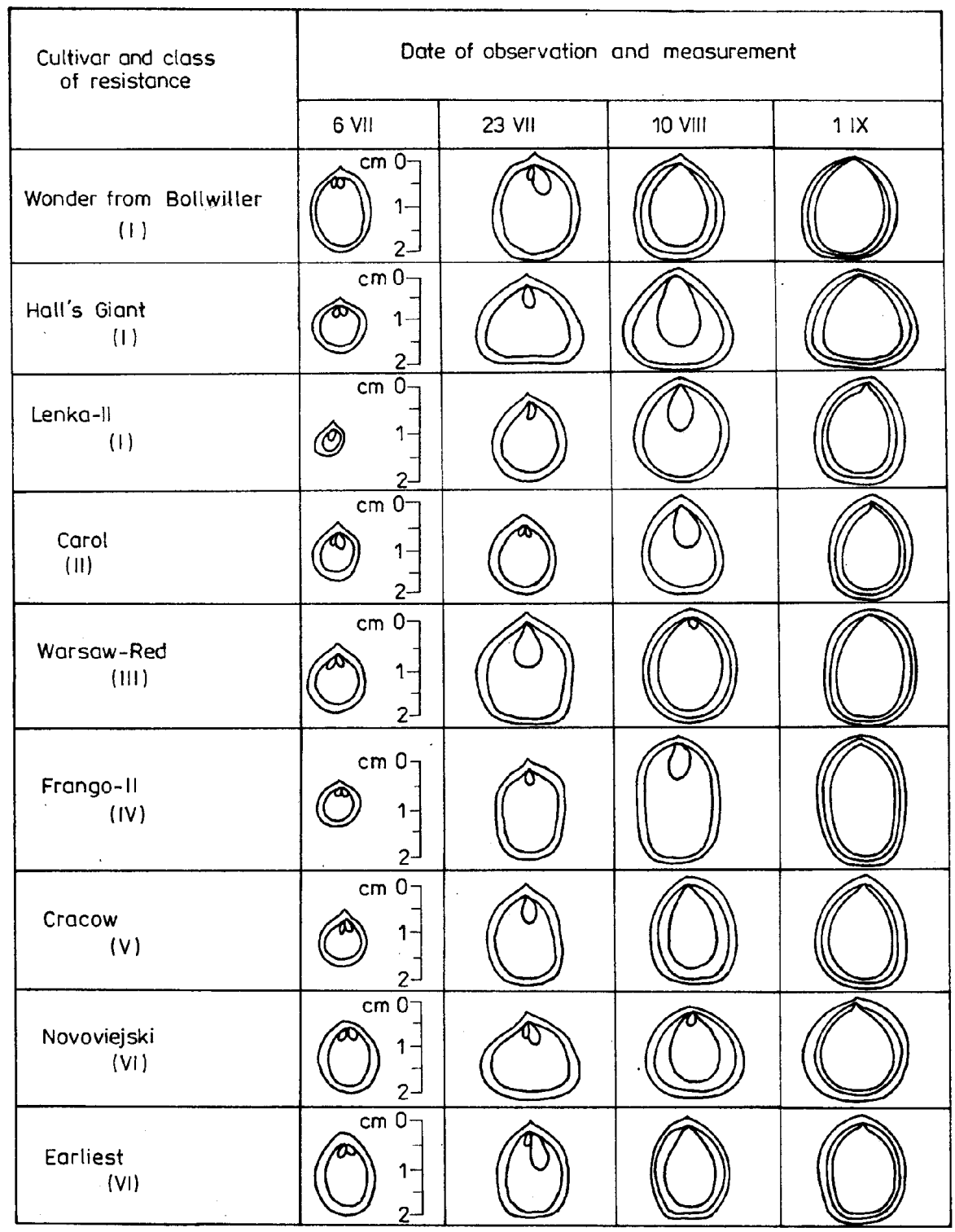

Fig. 2. The development of the shell (pericarp) and kernel (embryo with its cotyledons) in nuts of 9 hazel cultivars differing in resistance to hazelnut weevil

one ovule was visible from this early stage of development. The remaining space in the developing nut was filled with endosperm. The measurements made on July 23 showed far smaller differences between the cultivars in the size of their nutlets while differences in the size of the developing embryos were significant. The largest embryos were found in the nuts from early cultivars, 
Warsaw Red (class III) and Earliest (class VI), while the smallest were in the late and moderately late varieties. The resistance to hazelnut weevil was not dependent on the size of the embryo at this date. The nutlets of resistant and susceptible cultivars had similar sized embryos. Measurements made in August showed that the differences in nut size of the various cultivars further diminished, with some of the nuts reaching their mature size at this point, e.g. Wonder from Bollwiller, Warsaw Red and Earliest. The size of the embryo was still varied. The cotyledons of the early cultivars, e.g. Warsaw Red and Earliest filled almost the whole of the nut and the endosperm was almost totally hydrolyzed. The embryos of the late cultivars were at this point still small and the endosperm still firm. On September 1, all of the nuts reached their final size and those of the early cultivars were ready for harvest. The cotyledons filled almost the entire nut, even in the late varieties. Only small amounts of hydrolyzed endosperm were found in innumerous nuts.

Columns 5 and 6 of Table 1 give the results of measurements of pericarp thickness made in two successive years during the period of intense oviposition by the weevil (1981) and at the start of this period (1982). These measurements did not show any relationship between the thickness of the pericarp of the developing nuts and the resistance class of the cultivars. The correlation coefficients given at the bottom of columns 5 and 6 are insignificant at the $5 \%$ level for both measurement dates.

The results of determining the hardness of the developing nuts of 20 varieties of hazel, made during oviposition (July 9, 1982) and hatching and development of larvae (August 5, 1982), are presented in columns 7 and 8 of Table 1. On the first measurement date, the nut shells of all of the cultivars were not hard and the results ranged from $1.8 \mathrm{~N}$ in Frango-II to $4.3 \mathrm{~N}$ in Novoviejski. No correlation was found at this point between the resistance class of the cultivars and the pericarp hardness. The measurements made in August revealed that the pericarp hardened very much, with the results ranging from $62.9 \mathrm{~N}$ in Lenka-III to $177.9 \mathrm{~N}$ in the thick-shelled cultivar, Frango-I. The measurements at this date also showed no correlation between the hardness of the pericarp and the resistance class of the cultivars (the correlation coefficients are given at the bottom of columns 7 and 8 in Table 1).

The resutls of the laboratory feeding preference experiments conducted at the start of feeding stage of the pest on developing nutlets, are shown in Table 3. They show that the weevils fed most frequently on the varieties with the largest nutlets, irrespective of the resistance class of the cultivar. Correlation analysis revealed a strict dependence between the size of the nutlet and the mean number of punctures in the pericarp made by the hazelnut weevil (the correlation coefficient $r=0.830$, significant at the $1 \%$ level). No correlation, however, was found at this initial feeding stage between the resistance class of the variety and the mean number of punctures on the pericarp. 


\section{DISCUSSION}

There is a common opinion among hazelnut growers that the cultivars susceptible to hazelnut weevil are those with the thinnest shell, while those with thick shells are resistant. Lęs ka (1973) also expressed this view in her paper, but did not support this claim experimentally. Our own observations (P is kornik, 1989) have shown numerous exemptions from this rule. The low and nonsignificant correlation coefficients given in Table 1 indicate that the resistance of hazel to hazelnut weevil does not depend on either the pericarp thickness or its hardness. The pericarp of the developing hazelnuts during the feeding and oviposition stages, that is, in July, is not an effective barrier for the mouth apparatus of the insect, even though there are certain differences in the degree of lignification of this tissue. This is shown by the lack of a significant correlation between the degree of pericarp lignification and the mean number of damaged nuts (Table 1, columns 3 and 4). The course of lignification of the pericarp in the particular cultivars is rather diversified (Table 2), but the

Table 2

Dynamics of pericarp lignification during the development of 9 hazel cultivars

\begin{tabular}{rlcccc}
\hline \multirow{2}{*}{$\begin{array}{c}\text { Class of } \begin{array}{c}\text { Colignification in the } 6 \text { point scale, } \\
\text { mesistance }\end{array} \\
\end{array}$} & \multicolumn{4}{c}{$\begin{array}{c}\text { Cusured } \\
\text { on }\end{array}$} \\
\cline { 3 - 6 } & & 6 VII & 23 VII & 10 VIII & 1 IX \\
\hline I & Wonder from Bollwiller & $1-3$ & 5 & 5 & 5 \\
I & Hall's Giant & $1-2$ & $3-5$ & 5 & 5 \\
I & Lenka-II & 1 & 2 & $3-5$ & 5 \\
II & Carol & $0-2$ & $1-2$ & $4-5$ & 5 \\
III & Warsaw-Red & $2-3$ & $4-5$ & 5 & 5 \\
IV & Frango-II & $1-2$ & $1-2$ & $2-5$ & $4-5$ \\
V & Cracow & $1-2$ & $1-4$ & $4-5$ & 5 \\
VI & Novoviejski & $1-2$ & $3-5$ & 5 & 5 \\
VI & Earliest & $1-2$ & $4-5$ & 5 & 5 \\
\hline
\end{tabular}

Note: Six point lignification scale: 0 - nonlignified pericarp, $1-4$ increased lignification of the pericarp, 5 - lignified pericarp.

amount of lignin in this tissue during the period of oviposition does not seem to significantly hamper this process.

No dependence was also found between the rate of embryo development and the resistance of the cultivar to the hazelnut weevil (Fig. 2). Considerable differences in the rate of embryo development are found both in resistant and susceptible cultivars.

According to Łęska (1973), the feeding of the beetles on the nuts begins 
when the nuts reach the size of a pea. Because there are considerable differences among cultivars in the size of nutlets in the initial stages of their development, it was necessary to check if their size is a factor in determining the feeding preferences of the beetles. The laboratory experiments conducted in the third decade of June showed that the beetles did in fact prefer to feed on larger nutlets at this stage, while did not choose those at a less advanced stage of development. This is shown by the high value of the correlation coefficient, siginificant at the $1 \%$ level, between the size of the nutlets and the mean number of punctures on the pericarp made by the feeding of the beetles (Table 3). At this stage, no correlation was found between the resistance class of the cultivars and the feeding frequencies. This, however, changed in July during the period of intense oviposition when the differences in the size of the nutlets decreased and feeding and oviposition could take place on all of the cultivars. The results of a previous paper (Pisk ornik, 1989) show that in July, a strict

\section{Table 3}

The relationship between the size of fruitlets of 19 hazel cultivars, and feeding frequency of hazelnut weevil beetles at the very beginning of oviposition (June 23-25,

1983)

\begin{tabular}{|c|c|c|c|c|}
\hline \multirow[t]{2}{*}{ Cultivar } & \multirow[t]{2}{*}{$\begin{array}{c}\text { Class } \\
\text { of resistance } \\
\text { in } 1982\end{array}$} & \multicolumn{2}{|c|}{$\begin{array}{l}\text { Mean size of } \\
\text { fruitlets } \\
(\mathrm{mm})\end{array}$} & \multirow{2}{*}{$\begin{array}{c}\text { Feeding } \\
\text { frequency }- \text { no. } \\
\text { of punctures/fruit- } \\
\text { let } / 48 \mathrm{~h}\end{array}$} \\
\hline & & width & height & \\
\hline Lenka-II & I & 4.1 & 5.2 & 0 \\
\hline Frango-II & IV & 4.4 & 5.2 & 0.7 \\
\hline Cracow & V & 6.7 & 7.3 & 1.2 \\
\hline Truchsess Zellernuss & V & 6.4 & 8.0 & 1.9 \\
\hline Catalan & II & 7.5 & 7.7 & 1.9 \\
\hline Justovski Late & V & 7.7 & 7.6 & 0.2 \\
\hline Lenka-II & IV & 7.6 & 8.2 & 1.3 \\
\hline Lenka-III & II & 7.1 & 8.8 & 4.7 \\
\hline Volski Round & III & 8.2 & 9.3 & 2.7 \\
\hline Bomb & IV & 8.1 & 10.9 & 1.8 \\
\hline Gubener Zellernuss & III & 9.6 & 10.1 & 3.9 \\
\hline Starovolski & $\mathrm{V}$ & 8.7 & 11.4 & 3.5 \\
\hline Wonder from Bollwiller & $\mathbf{I}$ & 9.9 & 12.3 & 3.8 \\
\hline Frango-I & IV & 11.1 & 11.4 & 4.8 \\
\hline Webb's Prize Nut & III & 9.8 & 13.3 & 3.5 \\
\hline Warsaw-Red & III & 11.0 & 13.2 & 3.4 \\
\hline Earliest & VI & 10.3 & 14.1 & 5.2 \\
\hline Novoviejski & V & 11.4 & 13.6 & 4.6 \\
\hline Hall's Giant & I & 12.7 & 15.7 & 5.4 \\
\hline
\end{tabular}

Note: The correlation coefficient between the size of the nutlets and mean number of punctures on the pericarp, $r=0.830$ is significant at the $1 \%$ level, but insignificant correlation was found between the class of hazel cultivar resistance and the mean number of punctures on the pericarp $(r=0.311)$. 
dependence is found between the resistance of the cultivar and the feeding frequency of the beetles on developing nuts. This suggests that one of the factors influencing the resistance of certain hazel cultivars to the hazelnut weevil may be the chemical composition of the endosperm of the developing nutlets, which is both the food for the beetle in July as well as the site of oviposition.

During oviposition, which lasts from the end of June to the third decade of July, the beetles were able to choose from a large number of cultivars differing significantly in the degree and rate of nutlet development. At each moment of oviposition, the females were able to choose among cultivars with nuts showing the appropriate degree of development of both the pericarp as well as the tissues inside the nut. The fact that in the case of several cultivars, they did not choose them for the purpose of completing their life cycle, seems to indicate that there are factors other than the physical and chemical properties of the pericarp or the nutlet development rate which play an important role in the phenomenon of the varied resistance of hazel cultivars to hazelnut weevil.

\section{REFERENCES}

Broda B., 1971. Metody histochemii roślinnej. PZWL, Warszawa.

Łęska W., 1973. Badania nad biologią słonkowca orzechowca - Curculio (Balaninus) nucum L.

(Col., Curculionidae) i jego niszczeniem. Pol. Pismo Entomol. 43: 861-873.

Piskornik Z., 1989. The resistance of hazel (Corylus avellana L.) to hazelnut weevil (Curculio nucum L., Coleoptera, Curculionidae). Part I. Evaluation of the resistance of several cultivars. Acta Agrobot. 42: 123-131.

Odporność leszczyny (Corylus avellana L.) na słonkowca orzechowca (Curculio nucum L. - Coleoptera, Curculionidae)

Część II. Właściwości fizykochemiczne owocni i dynamika rozwoju orzechów, a odporność odmian na szkodnika

\section{Streszczenie}

Wśród 22 odmian leszczyny stwierdzono znaczne różnice w odporności na słonkowca orzechowca (Curculio nucum L.), który jest głównym szkodnikiem tej rośliny. Badano zależność między odpornością odmian na szkodnika a właściwościami fizykochemicznymi owocni, tj. dynamiką lignifikacji, zmianami w grubości i twardości w czasie rozwoju owocu oraz szybkością rozwoju zawiązków orzechów. Posługując się rachunkiem korelacyjnym nie stwierdzono zależności między właściwościami fizykochemicznymi owocni a odpornością odmian leszczyny na słonkowca orzechowca. Nie wykazano również związku między dynamiką rozwoju orzecha a odpornością na szkodnika. W początkowym okresie żerowania chrząszczy na zawiązkach orzechów i poszukiwaniu miejsca do złożenia jaj owad wydaje się preferować odmiany o największych zawiązkach owoców, co stwierdzono w laboratoryjnym doświadczeniu pokarmowym. W okresie intensywnego składania jaj, o wyborze odmiany przez chrząszcze wydają się decydować inne cechy zawiązków orzechów, a nie ich wielkość. 